\title{
Pharmacies for the Pharmacists-Ukrainian Fears and Polish Experiences
}

\author{
Tomasz Zaprutko ${ }^{1, *(\mathbb{D}}$, Bohdan Hromovyk ${ }^{2}$, Roman Lesyk ${ }^{3,4} \mathbb{D}^{-}$, Lilia Lesyk ${ }^{5}{ }^{(0)}$, \\ Yuliia Kremin ${ }^{2}{ }^{\circledR}$, Krzysztof Kus ${ }^{1}$, Dorota Kopciuch ${ }^{1}$, Piotr Ratajczak ${ }^{1}{ }^{1}$, Anna Paczkowska ${ }^{1}$ \\ and Elżbieta Nowakowska ${ }^{1}$ \\ 1 Department of Pharmacoeconomics and Social Pharmacy, Poznan University of Medical Sciences, \\ 7 Rokietnicka Street, 60-806 Poznań, Poland; kkus@ump.edu.pl (K.K.); dorota.kol@vp.pl (D.K.); \\ p_ratajczak@ump.edu.pl (P.R.); aniapaczkowska@ump.edu.pl (A.P.); farmakoekonomika@ump.edu.pl (E.N.) \\ 2 Department of organization and economics of pharmacy, Danylo Halytsky Lviv National Medical University, \\ 69 Pekarska, 79010 Lviv, Ukraine; hromovyk@gmail.com (B.H.); Kremin_Julia@i.ua (Y.K.) \\ 3 Department of Pharmaceutical, Organic and Bioorganic Chemistry, Danylo Halytsky Lviv National Medical \\ University, 69 Pekarska, 79010 Lviv, Ukraine; dr_r_lesyk@org.lviv.net \\ 4 Department of Public Health, Dietetics and Lifestyle Disorders, Faculty of Medicine, \\ University of Information Technology and Management in Rzeszow, Sucharskiego 2, \\ 35-225 Rzeszow, Poland \\ 5 Lviv Polytechnic National University, Institute of Economics and Management, \\ Department of Business Economics and Investment, 5 Metropolian Andrey str., Building 4, 79005 Lviv, \\ Ukraine; lilia.lesyk@gmail.com \\ * Correspondence: tomekzaprutko@ump.edu.pl; Tel.: +48-61-8542684
}

Received: 16 December 2019; Accepted: 23 January 2020; Published: 6 February 2020

\begin{abstract}
In 2017, a regulation referred to as "pharmacies for the pharmacists" was implemented in Poland, and Ukraine is going to implement a similar act of law. The study was to collect Ukrainian pharmacists' opinions about the upcoming market regulation and to compare their views with opinions obtained from Polish pharmacists collected two years following the amendment of this legislation. The study was conducted in Poland and Ukraine using a self-designed questionnaire. Of 2162 questionnaires received, 2043 were included in the study (1623 from Ukraine and 420 from Poland). Ukrainian pharmacists $(76.8 \%)$ feared that medicine prices would increase. Moreover, they presented concerns related to poorer access to pharmaceuticals and reduced turnovers of pharmacies. Two years after the market regulation, $55.23 \%$ of Polish pharmacists pointed out that none of the fears reported in Ukraine were observed in Poland. However, $33.10 \%$ revealed that market regulation led to "a reduction in the number of pharmacies". Ukrainian pharmacists are afraid of community pharmacies' regulation. Polish pharmacists, however, have not observed such problems during the two years following the market regulation. The only noticeable market change in Poland was the reduced number of pharmacies.
\end{abstract}

Keywords: pharmacy; pharmaceutical law; market regulations; fears; pharmacists' opinions; Poland; Ukraine

\section{Introduction}

Community pharmacies have an important role in the healthcare system [1]. These facilities and pharmacists employed there are supposed to provide access to medicines, health promotion, and advice concerning the safe and effective use of pharmaceuticals [1-3]. However, in some countries, the role of pharmacists is limited to dispensing medicines [4]. Considering the significant role of pharmacists in activities such as pharmaceutical care [2], as well as the importance of affordability of 
medicines [5,6], pharmacy markets are changing [7] to become patient-focused and to improve access to medicines and market competitions between pharmacies $[2,8,9]$.

Countries such as the UK and Norway run procompetitive policies. Spain or Austria, however, are examples of regulated markets where pharmacies can only be owned by pharmacists and where horizontal integration is observed $[1,8,10]$. Although restrictions on ownership and location of pharmacies seem to contradict the freedom of establishment and free movement of capital in the European Union (EU), the European Court of Justice ruled that these regulations might be justified in the case of pharmacies and that EU members may impose individual restrictions on their pharmacy markets [8].

In deregulated markets, it is assumed that greater competition would lead to a reduction of medicine prices, higher quality, and a greater range of pharmaceutical services [7-9]. Moreover, supporters of liberalization claim that deregulation contributes to better access to medicines, owing to a greater number of pharmacies and longer opening hours $[2,7,8]$. It has also been pointed out that stronger competition makes patients more empowered, as they are capable of choosing their own healthcare [2]. However, there are voices in favor of regulated markets. Their doubts concerning deregulation are related to poorer access to pharmaceuticals in rural areas and for vulnerable groups of patients [8]. Some EU member states justify restrictions by claiming that pharmacy market regulations guarantee the independence of pharmacists, as well as the quality and equality of service [10].

Although community pharmacy chains have become more prevalent, some European countries maintain a regulated pharmacy market [11]. Countries such as Estonia, Hungary, and Poland decided to amend the law towards a reduced degree of liberalism in pharmaceutical policies [1,4]. In Poland, early in April 2017, the president signed an act referred to as "pharmacies for the pharmacists". It specifies who can own a pharmacy and regulates demographic and geographic criteria [4]. In Poland, there are approximately 14,000 pharmaceutical points of sale, of which $91 \%$ are pharmacies and $9 \%$ are limited-service pharmacies $[4,12,13]$. According to the amended law, a new entity may be opened if the distance between the location of the planned pharmacy and the nearest community pharmacy is at least $500 \mathrm{~m}$ and if the number of individuals per pharmacy $\geq 3000$ persons [4]. Furthermore, the main owner of the pharmacy should be a person with a degree in pharmacy who is allowed to run and own up to four community pharmacies [4]. However, the law is not retroactive and applies only to newly opened pharmacies. Hence, if someone previously owned a pharmacy chain, they can still run their company in the same way. Ukraine-Poland's eastern neighbor-is going to emulate Polish regulations in terms of geographical and ownership restrictions. The minimum distance between pharmacies would have to be $500 \mathrm{~m}$, and only pharmacists would be allowed to own a pharmacy. They will also be allowed to run up to four pharmacies. Same as in Poland, however, the law would not be retroactive. Hence, existing pharmacies would be able to continue their business.

In Ukraine, there are about 20,500 points of pharmaceuticals sales, of which $80 \%$ constitute pharmacies and $20 \%$ limited-service pharmacies. The majority of these entities are situated in urban areas and, due to the market changes, their number is lower than a few years ago [14]. Interestingly, there used to be pharmacy kiosks in Ukraine. Their main purpose was to provide quick and common access to over-the-counter (OTC) medicines and dressing supplies. Nevertheless, at the end of 2012, kiosks were no longer available, e.g., due to the lack of storage quality and frequent turnover of prescription medicines [15]. However, the market is characterized by a gradual and stable growth, [16] with $40 \%$ of the Ukrainian pharmacy market nowadays covered by the 20 largest pharmacy chains [17]. Despite this, several fears and objections related to the proceeded regulations have been raised in Ukraine. The most frequent concern is an increase in drug prices and reduced access to pharmaceuticals.

The aim of the study was to collect the opinions of Ukrainian pharmacists about the upcoming market regulations and to compare their views with the opinions of Polish pharmacists collected two years following the amendment of the pharmaceutical law. 


\section{Materials and Methods}

The study was conducted between January 2019 and May 2019 using a self-designed questionnaire comprising six questions in Poland and five questions in Ukraine and a short socio-demographic section. To our knowledge, there is a lack of similar studies abroad; thus, we were not able to follow some examples from other countries. However, as pharmacists, and based on the literature concerning pharmaceutical market regulations, we were able to create a questionnaire. In both versions, the questions concerned the same issues. The questions and possible variants of the answers are presented in Table 1.

Table 1. Questions used in the survey.

\begin{tabular}{|c|c|c|}
\hline Question & Question Content & Possible Answers \\
\hline $1^{\#}$ & $\begin{array}{l}\text { Did you fear the increase in the prices of pharmaceuticals } \\
\text { as a result of the act "pharmacy for the pharmacist"? }\end{array}$ & Agree/disagree \\
\hline $2^{\#}$ & $\begin{array}{l}\text { Did you fear reducing access to medicinal products as a } \\
\text { result of geographical and demographic regulations as a } \\
\text { result of the act "pharmacy for the pharmacist"? }\end{array}$ & Agree/disagree \\
\hline $3^{\#}$ & $\begin{array}{l}\text { Were you afraid of the monthly turnover of the pharmacy } \\
\text { reducing as a result of the introduction of the act } \\
\text { "pharmacy for the pharmacist"? }\end{array}$ & Agree/disagree \\
\hline $4^{\#}$ & $\begin{array}{l}\text { Were you afraid of the number of pharmacies reducing as a } \\
\text { result of the introduction of the act "pharmacy for the } \\
\text { pharmacist"? }\end{array}$ & Agree/disagree \\
\hline $5 *$ & $\begin{array}{c}\text { Do you think that the act "pharmacy for the pharmacist" } \\
\text { may lead to the development of pharmaceutical care and } \\
\text { improve the quality of pharmaceutical services provided } \\
\text { by the pharmacy? }\end{array}$ & Agree/disagree \\
\hline \multirow{5}{*}{6} & \multirow{5}{*}{$\begin{array}{l}\text { Which of the problem listed above was found in market } \\
\text { realities as a consequence of the act "pharmacy for the } \\
\text { pharmacist"? }\end{array}$} & $\begin{array}{l}\text { - Price increases of } \\
\text { pharmaceuticals (Question 1) }\end{array}$ \\
\hline & & $\begin{array}{l}\text { - } \\
\text { due to geographical and } \\
\text { demographic regulations } \\
\text { (Question 2) }\end{array}$ \\
\hline & & $\begin{array}{ll}\text { - } & \text { Reduction of pharmacy } \\
\text { turnovers (Question 3) }\end{array}$ \\
\hline & & $\begin{array}{l}\text { The decrease in the total } \\
\text { number of pharmacies } \\
\text { (Question 4) }\end{array}$ \\
\hline & & None of the listed points \\
\hline
\end{tabular}

\# In the Ukrainian version, these questions were asked in present tense. * In the Ukrainian version, this question was asked in the future tense. 'Question asked only to Polish participants.

In Ukraine, the questions concerned fears and expected market changes as a result of the incoming market regulation. In the Polish version, however, questions were constructed to assess whether Polish pharmacists had been afraid of market changes related to the "pharmacies for the pharmacists" act. The additional question asked of Polish pharmacists was aimed at examining whether any of the concerns related to the market restrictions were reflected in reality 2 years after the implementation of said legislative act. Before the exact analysis, a pilot study was conducted among 10 pharmacists. It allowed us to clarify the questions and to create a final version of the study tool.

Participation in the study was voluntary, personal data were not gathered, and no incentives were offered. The answers were collected in urban and rural areas in both countries. Answers collected in Poland come from the following cities: Warsaw (the capital), Cracow, Poznan, Gdansk, Wroclaw, Lublin, Katowice, and surrounding regions. Answers collected in Ukraine also come from the entire country, i.e., Kyiv (the capital), Lviv, Odesa, Dnipro, Vinnytsia, Chernivtsi, Mykolaiv, Zaporizhia, and surrounding regions. 
The questionnaire was delivered by direct contact (visit at the pharmacy) or sent via e-mail, if expected by potential participants. The respondents were requested to return filled-in questionnaires via e-mail or, if necessary, the sheets were collected directly from the pharmacy. We collected one reply per pharmacy filled in by the professional staff. Some pharmacists refused to join the study, especially due to the terms of their contracts. Although it seems easy to connect the e-mail with the pharmacy's location, it was not our aim to collect and then present such data. We would not be accused of pharmacy advertising, which is strictly forbidden in Poland [5].

Of 2162 questionnaires received, 2043 were included in the study. Collected in Ukraine were 1623 and 420 in Poland. Excluded were 119 questionnaires, since they were filled in incorrectly, i.e., there was no answer provided in one of the questions or the socio-demographic section was not filled in. Before the study, we expected to collect 500 questionnaires in Poland and 1000 in Ukraine. Considering the opinions of our research team, we stated that pharmacists in Ukraine were not so over-researched as in Poland; thus, we expected more answers from Ukraine. This was reflected in reality. Nonetheless, the number of obtained answers, as well as the inclusion of pharmacies from the entire countries, seemed to make the sample representative.

Pharmacists' answers were divided depending on the type of pharmacy (individual, mini-chain of 2-4 pharmacies, chain of 5 to 15 pharmacies, and chain of $>15$ pharmacies) and its location (country, town with a population of $<20,000$ citizens, city with a population of up to 100,000 , and city with a population of $>100,000)$. The distinction of the type of pharmacy depending on the number of pharmacies in the structure is commonly used in market analyses. In the case of the location, however, we based that on statistical offices in Poland and Ukraine, and we used average values to make the study homogenous.

\section{Statistical Analysis}

The countries were compared in a chi-square test of independence. Post hoc tests were performed by analysis of the test for proportions. The analysis was performed using Statistica 13.1 (StatSoft, Cracow, Poland). All tests were considered significant at $p<0.05$.

\section{Results}

Results from both countries concern individual and chain pharmacies and were collected both in rural and urban areas. The exact distribution of socio-demographic results are presented in Table 2.

In the first three questions of the study tool, Ukrainian respondents mainly decided to choose affirmative answers, indicating that they were afraid of price increases, reduced access to medicines, and reduced turnover of their pharmacies as a result of upcoming market regulations. Conversely, the majority of Polish respondents indicated that they were not concerned about these aspects at the time of implementation of the "pharmacies for the pharmacists" act.

In terms of concerns related to the decrease in the number of pharmacies, answers from both countries were convergent. In Ukraine, $57.5 \%$ of study participants were not afraid of such market changes, while, in Poland, it was $65 \%$. Results were distributed relatively evenly also in terms of the statement that "pharmaceutical market regulation may contribute to the development of pharmaceutical care and improvement of the quality of pharmaceutical services". In Ukraine, 51.1\% of respondents agreed with this point of view, while, in Poland, it was $57.6 \%$. The exact distribution of results obtained from Questions 1 to 5 is presented in Table 3.

In the question asked only of Polish pharmacists, the respondents were to evaluate which of the fears (Questions 1-4) they found valid two years following the law amendment. The most frequent answer was "none of the listed points", chosen by $55.23 \%$ of pharmacists and followed by "decrease in the number of pharmacies" (33.10\%). The "increase in prices of pharmaceuticals" option was checked by $5.95 \%$ of study participants. The answers related to the decrease of the pharmacy turnover and to the reduced access to medicines were chosen by $2.86 \%$ of Polish pharmacists.

The distribution of results in relation to the type of pharmacy and pharmacy location is presented in Table 4. 
Table 2. The distribution of socio-demographic results.

\begin{tabular}{|c|c|c|c|c|c|c|c|c|}
\hline & \multicolumn{4}{|c|}{ Type of Pharmacy } & \multicolumn{4}{|c|}{ Location } \\
\hline & Individual & $\begin{array}{l}\text { Mini-Chain 2-4 } \\
\text { Pharmacies }\end{array}$ & $\begin{array}{l}\text { Chain with } 5 \text { to } \\
15 \text { Pharmacies }\end{array}$ & $\begin{array}{c}\text { Chain with }>15 \\
\text { Pharmacies }\end{array}$ & Country & $\begin{array}{c}\text { Town }<20 \\
\text { Thousand Citizens }\end{array}$ & $\begin{array}{c}\text { City up to } 100 \\
\text { Thousand Citizens }\end{array}$ & $\begin{array}{c}\text { City Inhabited by }>100 \\
\text { Thousand Citizens }\end{array}$ \\
\hline Poland & $27.14 \%(n=114)$ & $23.33 \%(n=98)$ & $21.67 \%(n=91)$ & $27.86 \%(n=117)$ & $5.71 \%(n=24)$ & $19.05 \%(n=80)$ & $30.95 \%(n=130)$ & $44.29 \%(n=186)$ \\
\hline Ukraine & $19.6 \%(n=318)$ & $18.7 \%(n=304)$ & $19.4 \%(n=314)$ & $42.3 \%(n=687)$ & $10.8 \%(n=175)$ & $18.3 \%(n=297)$ & $19.6 \%(n=319)$ & $51.3 \%(n=832)$ \\
\hline
\end{tabular}

Table 3. Distribution of answers obtained in Questions 1 to 5.

\begin{tabular}{|c|c|c|c|c|c|c|c|c|c|c|c|c|c|c|c|}
\hline & \multicolumn{3}{|c|}{ Question 1} & \multicolumn{3}{|c|}{ Question 2} & \multicolumn{3}{|c|}{ Question 3} & \multicolumn{3}{|c|}{ Question 4} & \multicolumn{3}{|c|}{ Question 5} \\
\hline & Agree & Disagree & $p$ & Agree & Disagree & $p$ & Agree & Disagree & $p$ & Agree & Disagree & $p$ & Agree & Disagree & $p$ \\
\hline $\begin{array}{l}\text { Poland } \\
\text { Ukraine }\end{array}$ & $\begin{array}{c}21.4 \% \\
(n=90) \\
76.8 \% \\
(n=1246)\end{array}$ & $\begin{array}{c}78.6 \% \\
(n=330) \\
23.2 \% \\
(n=377)\end{array}$ & $p<0$ & $\begin{array}{c}12.6 \% \\
(n=53) \\
59.5 \% \\
(n=965)\end{array}$ & $\begin{array}{c}87.4 \% \\
(n=367) \\
40.5 \% \\
(n=658)\end{array}$ & $p<0$ & $\begin{array}{c}13.8 \% \\
(n=58) \\
61.2 \% \\
(n=994)\end{array}$ & $\begin{array}{c}86.2 \% \\
(n=362) \\
38.8 \% \\
(n=629)\end{array}$ & $p<0$ & $\begin{array}{c}35 \% \\
(n=147) \\
42.5 \% \\
(n=689)\end{array}$ & $\begin{array}{c}65 \% \\
(n=273) \\
57.5 \% \\
(n=934)\end{array}$ & $p=0.0056$ & $\begin{array}{c}57.6 \% \\
(n=242) \\
51.1 \% \\
(n=830)\end{array}$ & $\begin{array}{c}42.4 \% \\
(n=178) \\
48.9 \% \\
(n=793)\end{array}$ & $p=0.0178$ \\
\hline
\end{tabular}

Table 4. Data distribution in relation to the type of pharmacy and their location.

\begin{tabular}{|c|c|c|c|c|c|c|c|c|c|c|}
\hline & & & \multicolumn{4}{|c|}{ Type of Pharmacy } & \multicolumn{4}{|c|}{ Location } \\
\hline & & & Individual & $\begin{array}{l}\text { Mini-Chain 2-4 } \\
\text { Pharmacies }\end{array}$ & $\begin{array}{l}\text { Chain with } 5 \text { to } 15 \\
\text { Pharmacies }\end{array}$ & $\begin{array}{c}\text { Chain with > } 15 \\
\text { Pharmacies }\end{array}$ & Country & $\begin{array}{c}\text { Town }<20 \\
\text { Thousand Citizens }\end{array}$ & $\begin{array}{c}\text { City up to } 100 \\
\text { Thousand Citizens }\end{array}$ & $\begin{array}{l}\text { City Inhabited by } \\
>100 \text { Thousand } \\
\text { Citizens }\end{array}$ \\
\hline \multirow{4}{*}{ Poland } & Q1 & $\begin{array}{c}\text { agree } \\
\text { disagree } \\
p\end{array}$ & $\begin{array}{c}19.30 \% \\
(n=22) \\
80.70 \%^{*} \\
(n=92) p<0.0001\end{array}$ & $\begin{array}{c}19.30 \% \\
(n=18) \\
81.63 \%{ }^{*} \\
(n=80) p<0.0001\end{array}$ & $\begin{array}{c}18.68 \% \\
(n=17) \\
81.32 \%{ }^{*} \\
(n=74) p<0.0001 \\
\end{array}$ & $\begin{array}{c}28.21 \% \\
(n=33) \\
71.79 \% * \\
(n=84) p<0.0001\end{array}$ & $\begin{array}{c}41.67 \% \\
(n=10) \\
58.33 \% \\
(n=14) p=0.4208\end{array}$ & $\begin{array}{c}22.50 \% \\
(n=18) \\
77.50 \% \%^{*} \\
(n=62) p<0.0001 \\
p=c\end{array}$ & $\begin{array}{c}16.15 \% \\
(n=21) \\
83.85 \% * \\
(n=109) p<0.0001 \\
0443\end{array}$ & $\begin{array}{c}22.04 \% \\
(n=41)^{*} \\
77.96 \% \\
(n=145) p<0.0001\end{array}$ \\
\hline & Q2 & $\begin{array}{c}\text { agree } \\
\text { disagree } \\
p \\
\end{array}$ & $\begin{array}{c}5.26 \% \\
(n=6) \\
94.74 \% \%^{*} \\
(n=108) p<0.0001\end{array}$ & $\begin{array}{c}11.22 \% \\
(n=11) \\
88.78 \% * \\
(n=87) p<0.0001 \\
p= \\
p=\end{array}$ & $\begin{array}{c}15.38 \% \\
(n=14) \\
84.62 \%{ }^{*} \\
(n=77) p<0.0001 \\
.0151\end{array}$ & $\begin{array}{c}18.80 \% \\
(n=22) \\
81.20 \%{ }^{*} \\
(n=95) p<0.0001\end{array}$ & $\begin{array}{c}8.33 \% \\
(n=2) \\
91.67 \% \\
(n=22) \mathrm{NS}\end{array}$ & $\begin{array}{c}11.25 \% \\
(n=9) \\
88.75 \% \\
(n=71) \text { NS }\end{array}$ & $\begin{array}{c}13.08 \% \\
(n=17) \\
86.92 \% \\
(n=113) \mathrm{NS}\end{array}$ & $\begin{array}{c}13.44 \% \\
(n=25) \\
86.56 \% \\
(n=161) \mathrm{NS}\end{array}$ \\
\hline & Q3 & $\begin{array}{c}\text { agree } \\
\text { disagree } \\
p\end{array}$ & $\begin{array}{c}5.26 \% \\
(n=6) \\
94.74 \% * \\
(n=108) p<0.0001\end{array}$ & $\begin{array}{c}12.24 \% \\
(n=12) \\
87.76 \% * \\
(n=86) p<0.0001 \\
p=\end{array}$ & $\begin{array}{c}12.09 \% \\
(n=11) \\
87.91 \% *^{*} \\
(n=80) p<0.0001 \\
.0002\end{array}$ & $\begin{array}{c}24.79 \% \\
(n=29) \\
75.21 \% * \\
(n=88) p<0.0001\end{array}$ & $\begin{array}{c}8.33 \% \\
(n=2) \\
91.67 \% \\
(n=22) \mathrm{NS}\end{array}$ & $\begin{array}{c}7.50 \% \\
(n=6) \\
92.50 \% \\
(n=74) \text { NS }\end{array}$ & $\begin{array}{c}14.62 \% \\
(n=19) \\
85.38 \% \\
\quad \quad(n=111) \mathrm{NS} \\
\end{array}$ & $\begin{array}{c}16.67 \% \\
(n=31) \\
83.33 \% \\
(n=155) \text { NS }\end{array}$ \\
\hline & Q4 & $\begin{array}{c}\text { agree } \\
\text { disagree } \\
p\end{array}$ & $\begin{array}{c}26.32 \% \\
(n=30) \\
73.68 \%^{*} \\
(n=84) p<0.0001\end{array}$ & $\begin{array}{c}31.63 \% \\
(n=31) \\
68.37 \%{ }^{*} \\
(n=67) p<0.0001 \\
p=\end{array}$ & $\begin{array}{c}30.77 \% \\
(n=28) \\
69.23 \%^{*} \\
(n=63) p<0.0001 \\
.0012\end{array}$ & $\begin{array}{c}49.57 \% \\
(n=58) \\
50.43 \% * \\
(n=59) p<0.0001\end{array}$ & $\begin{array}{c}16.67 \% \\
(n=4) \\
83.33 \% \\
(n=20) \text { NS }\end{array}$ & $\begin{array}{c}33.75 \% \\
(n=27) \\
66.25 \% \\
(n=53) \text { NS }\end{array}$ & $\begin{array}{c}36.92 \% \\
(n=48) \\
63.08 \% \\
(n=82) \mathrm{NS}\end{array}$ & $\begin{array}{c}36.56 \% \\
(n=68) \\
63.44 \% \\
(n=118) \text { NS }\end{array}$ \\
\hline
\end{tabular}


Table 4. Cont

\begin{tabular}{|c|c|c|c|c|c|c|c|c|c|c|}
\hline & & & \multicolumn{4}{|c|}{ Type of Pharmacy } & \multicolumn{4}{|c|}{ Location } \\
\hline & & & Individual & $\begin{array}{l}\text { Mini-Chain 2-4 } \\
\text { Pharmacies }\end{array}$ & $\begin{array}{l}\text { Chain with } 5 \text { to } 15 \\
\text { Pharmacies }\end{array}$ & $\begin{array}{c}\text { Chain with > } 15 \\
\text { Pharmacies }\end{array}$ & Country & $\begin{array}{c}\text { Town }<20 \\
\text { Thousand Citizens }\end{array}$ & $\begin{array}{c}\text { City up to } 100 \\
\text { Thousand Citizens }\end{array}$ & $\begin{array}{c}\text { City Inhabited by } \\
>100 \text { Thousand } \\
\text { Citizens }\end{array}$ \\
\hline & Q5 & $\begin{array}{c}\text { agree } \\
\text { disagree } \\
p\end{array}$ & $\begin{array}{c}68.42 \% \\
(n=78) \\
31.58 \%{ }^{*} \\
(n=43) p=0.0001\end{array}$ & $\begin{array}{c}56.12 \% \\
(n=55) \\
43.88 \% \\
(n=43) p=0.2322 \\
p=\end{array}$ & $\begin{array}{c}65.93 \% \\
(n=60) \\
34.07 \% * \\
(n=31) p=0.0038 \\
.0002\end{array}$ & $\begin{array}{c}41.88 \% \\
(n=49) \\
58.12 \% \\
(n=68) p=0.0829\end{array}$ & $\begin{array}{c}50.0 \% \\
(n=12) \\
50.0 \% \\
(n=12) \mathrm{NS}\end{array}$ & $\begin{array}{c}58.75 \% \\
(n=47) \\
41.25 \% \\
(n=33) \text { NS }\end{array}$ & $\begin{array}{c}56.15 \% \\
(n=73) \\
43.85 \% \\
(n=57) \mathrm{NS}\end{array}$ & $\begin{array}{c}59.14 \% \\
(n=110) \\
40.86 \% \\
(n=76) \text { NS }\end{array}$ \\
\hline \multirow{5}{*}{ Ukraine } & Q1 & $\begin{array}{c}\text { agree } \\
\text { disagree } \\
p \\
\end{array}$ & $\begin{array}{c}76.73 \% \\
(n=273) \\
23.27 \% \%^{*} \\
(n=74) p<0.0001\end{array}$ & $\begin{array}{c}83.88 \% \\
(n=255) \\
16.12 \%{ }^{*} \\
(n=49) p<0.0001 \\
p< \\
p<\end{array}$ & $\begin{array}{c}50.96 \% \\
(n=160) \\
49.04 \% \\
(n=154) p=0.7337 \\
.0001\end{array}$ & $\begin{array}{c}85.44 \% \\
(n=587) \\
14.56 \% * \\
(n=100) p<0.0001 \\
\end{array}$ & $\begin{array}{c}96.00 \% \\
(n=168) \\
4.00 \% * \\
(n=7) p<0.0001\end{array}$ & $\begin{array}{c}85.86 \% \\
(n=255) \\
14.14 \% * \\
(n=42) p<0.0001 \\
\quad p<0\end{array}$ & $\begin{array}{c}89.97 \% \\
(n=287) \\
10.03 \% * \\
(n=32) p<0.0001 \\
.0001\end{array}$ & $\begin{array}{c}64.42 \% \\
(n=536) \\
35.58 \% * \\
(n=296) p<0.0001\end{array}$ \\
\hline & Q2 & $\begin{array}{c}\text { agree } \\
\text { disagree } \\
p\end{array}$ & $\begin{array}{c}58.18 \% \\
(n=185) \\
41.82 \%{ }^{*} \\
(n=133) p=0.0040\end{array}$ & $\begin{array}{c}57.89 \% \\
(n=176) \\
42.11 \%{ }^{*} \\
(n=128) p=0.0066 \\
p< \\
p<\end{array}$ & $\begin{array}{c}41.40 \% \\
(n=130) \\
58.60 \% * \\
(n=184) p=0.0027 \\
.0001\end{array}$ & $\begin{array}{c}69.00 \% \\
(n=474) \\
31.0 \% * \\
(n=213) p<0.0001\end{array}$ & $\begin{array}{c}80.57 \% \\
(n=141) \\
19.43 \% * \\
(n=34) p<0.0001\end{array}$ & $\begin{array}{c}64.98 \% \\
(n=193) \\
35.02 \%^{*} \\
(n=104) p<0.0001 \\
\quad p<0\end{array}$ & $\begin{array}{c}73.04 \% \\
(n=233) \\
26.96 \% * \\
(n=86) p<0.0001 \\
.0001\end{array}$ & $\begin{array}{c}47.84 \% \\
(n=398) \\
52.16 \% \\
(n=434) p=0.2132\end{array}$ \\
\hline & Q3 & $\begin{array}{c}\text { agree } \\
\text { disagree } \\
p \\
\end{array}$ & $\begin{array}{c}53.46 \% \\
(n=170) \\
46.54 \% \\
(n=148) p=0.2183\end{array}$ & $\begin{array}{c}70.07 \% \\
(n=213) \\
29.93 \% * \\
(n=91) p<0.0001 \\
p< \\
p<\end{array}$ & $\begin{array}{c}37.26 \% \\
(n=117) \\
62.74 \% * \\
(n=197) p<0.0001 \\
.0001\end{array}$ & $\begin{array}{c}71.91 \% \\
(n=494) \\
28.09 \% * \\
(n=193) p<0.0001\end{array}$ & $\begin{array}{c}81.14 \% \\
(n=142) \\
18.8 \%^{*} \\
(n=33) p<0.0001\end{array}$ & $\begin{array}{c}64.31 \% \\
(n=191) \\
35.69 \%^{*} \\
(n=106) p<0.0001 \\
\quad p<0\end{array}$ & $\begin{array}{c}74.61 \% \\
(n=238) \\
25.39 \%^{*} \\
(n=81) p<0.0001 \\
.0001\end{array}$ & $\begin{array}{c}50.84 \% \\
(n=423) \\
49.16 \% \\
(n=409) p=0.6280\end{array}$ \\
\hline & Q4 & $\begin{array}{c}\text { agree } \\
\text { disagree } \\
p\end{array}$ & $\begin{array}{c}38.99 \% \\
(n=124) \\
61.01 \% * \\
(n=194) p<0.0001\end{array}$ & $\begin{array}{c}35.53 \% \\
(n=108) \\
64.47 \% \%^{*} \\
(n=196) p<0.0001 \\
p< \\
p<\end{array}$ & $\begin{array}{c}27.39 \% \\
(n=86) \\
72.61 \% * \\
(n=228) p<0.0001 \\
0.0001\end{array}$ & $\begin{array}{c}54.00 \% \\
(n=371) \\
46.00 \% * \\
(n=316) p=0.0366\end{array}$ & $\begin{array}{c}47.43 \% \\
(n=83) \\
52.57 \% \\
(n=92) p=0.4971\end{array}$ & $\begin{array}{c}45.45 \% \\
(n=135) \\
54.55 \% \\
(n=162) p=0,1183 \\
\quad p<0\end{array}$ & $\begin{array}{c}55.17 \% \\
(n=176) \\
44.83 \% \\
(n=143) p=0.0662 \\
.0001\end{array}$ & $\begin{array}{c}35.46 \% \\
(n=295) \\
64.54 \% * \\
(n=537) p<0.0001\end{array}$ \\
\hline & Q5 & $\begin{array}{c}\text { agree } \\
\text { disagree } \\
p\end{array}$ & $\begin{array}{c}52.20 \% \\
(n=166) \\
47.80 \% \\
(n=152) p=0.4331\end{array}$ & $\begin{array}{c}55.92 \% \\
(n=170) \\
44.08 \% \\
(n=134) p=0.4020 \\
p< \\
p<\end{array}$ & $\begin{array}{c}67.20 \% \\
(n=211) \\
32.80 \% * \\
(n=103) p<0.0001 \\
.0001\end{array}$ & $\begin{array}{c}41.19 \% \\
(n=283) \\
58.81 \% \\
(n=404) p<0.0001\end{array}$ & $\begin{array}{c}38.86 \% \\
(n=68) \\
61.14 \% * \\
(n=107) p<0.0001\end{array}$ & $\begin{array}{c}51.85 \% \\
(n=154) \\
48.15 \% \\
(n=143) p=0.5247 \\
\quad p<0\end{array}$ & $\begin{array}{c}44.51 \% \\
(n=142) \\
55.49 \% \\
(n=177) p=0.0512 \\
.0001\end{array}$ & $\begin{array}{c}56.01 \% \\
(n=466) \\
43.99 \% * \\
(n=366) p=0.0002\end{array}$ \\
\hline
\end{tabular}

* Statistically significant difference $(p<0.05)$ between agree and disagree variants. NS means nonsignificant. 


\section{Discussion}

The analysis shows that the upcoming pharmaceutical market regulations in Ukraine arouse fears and doubts among Ukrainian pharmacists. They are commonly related to the increase in prices of pharmaceuticals or reduction of the pharmacies' turnovers and poorer access to medicines. Polish pharmacists, however, did not find these fears valid two years after the implementation of the "pharmacies for the pharmacists" act. Nonetheless, the question asked solely of Polish respondents showed that the only noticeable market change was associated with a reduced number of pharmacies.

Although pharmaceutical market decision-makers repeatedly face the choice between affordability, quality of service, and access to pharmaceuticals, these goals might be differently perceived. Supporters of deregulated markets claim that less regulation in the community pharmacy sector improves access to medicines and pharmacies and reduces pharmaceutical prices. Opponents of the deregulated market claim, however, that more regulation contributes, e.g., to a better quality of pharmacy services and to ensuring access to pharmacies in rural areas [8].

The results of our study indicate that implementation of the "pharmacies for the pharmacists" act in Poland did not cause any market disturbances, which is consistent with other analyses concerning the consequences of pharmaceutical market regulations $[1,8,10]$. Our results also confirm that the controlled market model may be associated with good access to pharmacies. In Austria, with a regulated pharmaceutical market, $92.6 \%$ of the population can reach a pharmacy within 10 min [11]. In Spain, which is another country with a regulated market, a good level of access to medicines has been achieved too [10]. Nevertheless, in Spain, financial incentives were reported for opening or maintaining pharmacies in remote areas [8], making the actual impact of market restrictions on access to pharmacies somewhat vague.

In Sweden, market deregulation was expected to ensure efficiency, better availability, price pressure, and safer usage of medicines [2]. Nevertheless, only the better availability of pharmacies and longer opening hours were achieved. The number of community pharmacies also increased significantly after deregulation in Norway, and this phenomenon was reported in all countries with deregulated markets [8]. New pharmacies were opened in urban areas with already good access to pharmacies but not in rural regions $[8,10]$. Considering facets associated with the availability of pharmacies in regulated and deregulated markets, the general statement that deregulation contributes to better access to pharmacies seems to be questionable. It is, therefore, not surprising that, contrary to fears observed among Ukrainian pharmacists, Polish respondents either in rural or in urban areas did not notice problems in access to medicines as an effect of the geographic and demographic criteria of the "pharmacies for the pharmacists" act.

According to the results of our study, Ukrainian pharmacists have not perceived a decrease in the number of pharmacies as a potential result of the upcoming market regulation. Prior to the implementation of the "pharmacies for the pharmacists" act, Polish respondents were also generally not afraid of a decrease in the number of pharmacies. However, almost $50 \%$ of Polish pharmacists representing chains of $>15$ pharmacies were afraid of a decrease in the number of pharmacies (Table 4 ). This might result from the structure of the biggest pharmacy chains, in which some points of sale are more or less profitable. Employees working in less profitable pharmacies could be afraid of restructuring, especially in urban areas. This may be mainly related to the fact that under the geographic and demographic restrictions a new pharmacy cannot be opened to replace a closed-down one [4].

Nevertheless, two years after the implementation of the "pharmacies for the pharmacists" act, $33.1 \%$ of Polish respondents pointed out that the market regulation resulted in a decrease in the number of pharmacies. This observation was confirmed by market data that claimed that 458 pharmacies were closed in Poland in 2018 [18]. The same effect of demographic and geographic regulations was observed in Estonia, where the number of community pharmacies decreased by $5 \%$ in urban areas and by $12 \%$ in the countryside [1]. This trend might be explained by the fact that some pharmacies were no longer profitable or were unable to effectively compete with other facilities [19]. 
It could be claimed that there were too many pharmacies in Poland, with approximately one community pharmacy per 2800 inhabitants. Sweden, before the abolishment of the pharmacy monopoly, had one pharmacy per 10,000 citizens, and after the market reregulation, the number of pharmacies increased by 400, so currently, there is one pharmacy per 7000 inhabitants [2]. In Germany, there is one community pharmacy per 4000 inhabitants and, in Portugal, one per 3600 inhabitants. The European Union average is one pharmacy per 3225 inhabitants $[7,20]$. These data may explain the reduction in the number of pharmacies in Poland. Moreover, the same trend might be expected in Ukraine, with a pharmacy density of one per 2100 inhabitants. The current density of pharmacies may foster competition that is too strong for independent pharmacies $[19,21]$.

In our study, Polish pharmacists were not afraid of an increase in prices of pharmaceuticals or a decrease in their pharmacies' turnovers. Nonetheless, pharmacists from pharmacies located in the country presented more fears related to price increases as an effect of the law amendment. This may result from different possibilities of price-negotiating power. If chain pharmacies, for instance, buy 1000 packages of OTC medicine, they are able to gain a better offer than an independent facility. The structure of the market shows that, in rural areas, there are more individual pharmacies, whereas, in cities, there are the biggest pharmacy chains.

Moreover, the minority indicated that such changes were observed two years after the implementation of the" pharmacies for the pharmacists" act. Contrarily, the majority of Ukrainian respondents presented fears about these market changes as a result of the upcoming amendments in the pharmaceutical law. Nonetheless, liberalized markets do not guarantee lower prices of medicines. Although pharmacists reported a financial pressure in the pharmacy margin and concerns about the turnover $[8,22]$, three years after the deregulation in Norway, the goal of drug price reductions have not been achieved [8]. Neither have the prices decreased following the deregulation in Sweden [2].

In Germany, Heinsohn and Flessa [9] proved that pharmacies characterized by patient-oriented services have higher turnovers and higher margins and, thus, are able to effectively compete with other outlets. This may be consistent with the results of our study, in which $51.1 \%$ of Ukrainian and $57.6 \%$ of Polish respondents claimed that market regulations might lead to the development of pharmaceutical care and improvements of pharmaceutical services. In addition to a better market position [9], pharmaceutical care may also lead to additional profits for pharmacies. Lakic et al. [23] and Jaber et al. [24] showed that patients were willing to pay for pharmaceutical care services. Pharmaceutical care was also cost-effective [25,26]; hence, healthcare decision-makers might consider financial incentives for such services. Despite this, a significant number of our study participants also objected to the importance of pharmaceutical care and the chances of the development of patient-oriented pharmaceutical services as results of market regulation. This point of view was mainly presented by Ukrainian and Polish pharmacists representing chains of more than 15 pharmacies (Table 4). This might be an effect of price competition among pharmacies and from the observation that the biggest chains located in urban areas might be more business-focused [1]. It could also result, as pointed out by Świeczkowski et al. [4], from the role of Polish pharmacists, who are limited in dispensing medicines. Nevertheless, the German example showed that patient-oriented services have been rather successful, owing to pharmacists' activities and not from any law amendments or the market deregulation implemented in Germany [9]. Therefore, market regulation in Poland and the incoming regulation in Ukraine may contribute to the development of pharmacists' activities in several healthcare services, and thus, may positively influence the perceptions of pharmacists, from dispensing medicines to pharmaceutical care. The decreased number of pharmacies, as a result of market regulation, may also lead to a competition between pharmacies and pharmacists themselves. It seems that better-organized facilities and open-minded and very well-educated staff will lead to market predominance. Additional services and patient-centered approaches at community pharmacies may also compensate for possible changes in the turnover of pharmacies. 
Lluch and Kanavos [10] demonstrated that countries with liberal or regulated markets may choose to adopt some of each other's policies. Decision-makers should bear this in mind if they want to build a system with good access to pharmacies and medicines. Comprehensive therapy should be available everywhere, because it is a right of every patient [6,27]. It also seems important to create a platform for patient-oriented competition based on pharmaceutical services, instead of solely price-based competition.

Limitations. It would be valuable to add more information on the existing evidence, data, and results of other studies describing the Polish pharmaceutical market before and after the regulation. Nonetheless, to our knowledge, there is a lack of similar analyses. Hence, the importance of this study. The study sample, especially in Poland, could have been larger. It would have been interesting to compare the prices of selected medicines ( $\mathrm{Rx}$ and OTC brands) between Poland and Ukraine and to present data about pharmacy turnovers before and after the market regulation. Nevertheless, it could be difficult to directly compare these data due to economic disparities between Poland and Ukraine.

It might be useful to use a five-point Likert scale to scale responses in the study. However, we aimed to simplify the questionnaire; thus, we decided to use the dichotomous reply system. It could be interesting to provide information on whether an electronic or direct collection of questionnaires was more effective. However, we have not decided to include that data, and each filled questionnaire was transferred to a common Excel sheet. Moreover, we offered a two-way (electronic and face-to-face) reply system to make the study flexible, clear, and the study tool more intelligible.

It could also be interesting to state if the results of Question 6 were statistically significant. Nevertheless, this question was asked only of Polish pharmacists; thus, we do not have statistically tested answers collected in relation to Question 6.

\section{Conclusions}

In the face of the upcoming market regulation, Ukrainian pharmacists are mainly afraid of increased drug prices, poorer access to medicines, and a decrease in the average turnover of their pharmacies. Two years after the implementation of the "pharmacies for the pharmacists" act, Polish pharmacists claim that none of the fears presented by their Ukrainian colleagues were observed in Poland. The only market change was a decrease in the number of pharmacies. Market regulation may contribute to an improvement in the quality of pharmaceutical care and lead to competition based on the quality of pharmaceutical services. The lack of information describing the Polish pharmaceutical market before and after regulation makes this study particularly important.

Author Contributions: Conceptualization, T.Z. and R.L.; methodology, T.Z., R.L., B.H., and L.L.; investigation, T.Z., L.L., R.L., B.H., Y.K., K.K., D.K., P.R., and A.P.; writing, T.Z., R.L., and B.H.; writing-review and editing, T.Z., R.L., B.H., L.L., and E.N.; visualization, T.Z., L.L., R.L., B.H., Y.K., K.K., D.K., P.R., A.P., and E.N.; and supervision, T.Z, R.L., B.H., and E.N. All authors have read and agreed to the published version of the manuscript.

Funding: This research received no external funding.

Conflicts of Interest: The authors declare no conflict of interest.

\section{References}

1. Gross, M.; Volmer, D. Restrictions to Pharmacy Ownership and Vertical Integration in Estonia-Perception of Different Stakeholders. Pharmacy 2016, 4, 18. [CrossRef] [PubMed]

2. Wisell, K.; Winblad, U.; Sporrong, S.K. Reregulation of the Swedish pharmacy sector-A qualitative content analysis of the political rationale. Health Policy 2015, 119, 648-653. [CrossRef] [PubMed]

3. Blouin, R.A.; Adams, M.L. The Role of the Pharmacist in Health Care Expanding and Evolving. N. C. Med. J. 2017, 78, 165-167. [PubMed]

4. Świeczkowski, D.; Merks, P.; Cwalina, N.; Jaguszewski, M.J. Development of Pharmacy Practice in European Countries-The Polish Perspective. Pharmacy 2017, 5, 43. [CrossRef] [PubMed] 
5. Zaprutko, T.; Kopciuch, D.; Kus, K.; Merks, P.; Nowicka, M.; Augustyniak, I.; Nowakowska, E. Affordability of medicines in the European Union. PLoS ONE 2017, 12, e0172753. [CrossRef] [PubMed]

6. Vogler, S.; Kilpatrick, K.; Babar, Z.-U.-D. Analysis of Medicine Prices in New Zealand and 16 European Countries. Value In Health 2015, 18, 484-492. [CrossRef] [PubMed]

7. Martins, L.; Queirós, S. Competition among pharmacies and the typology of services delivered: The Portuguese case. Health Policy 2015, 119, 640-647. [CrossRef] [PubMed]

8. Vogler, S.; Habimana, K.; Arts, D. Does deregulation in community pharmacy impact accessibility of medicines, quality of pharmacy services and costs? Evidence from nine European countries. Health Policy 2014, 117, 311-327. [CrossRef] [PubMed]

9. Heinsohn, J.G.; Flessa, S. Competition in the German pharmacy market: An empirical analysis. BMC Health Serv. Res. 2013, 13, 407. [CrossRef] [PubMed]

10. Lluch, M.; Kanavos, P. Impact of regulation of Community Pharmacies on efficiency, access and equity. Evidence from the UK and Spain. Health Policy 2010, 95, 245-254. [CrossRef] [PubMed]

11. Vogler, S.; Arts, D.; Sandberger, K. Impact of Pharmacy Deregulation and Regulation in European Countries; Gesundheit Österreich GmbH: Vienna, Austria, 2012; ISBN 978-3-85159-163-7.

12. Poland - More about pharmacy. EPhEU - Employed Community Pharmacists in Europe. Available online: https://epheu.eu/ (accessed on 3 January 2020).

13. Trend Spadkowy Trwa, Ale z Mniejszym Impetem-Finanse i Zarządzanie. Available online: http://www. rynekaptek.pl/marketing-i-zarzadzanie/trend-spadkowy-trwa-ale-z-mniejszym-impetem,31753.html (accessed on 28 May 2019).

14. Инчраструктура аптечного ритейла: на пороге изменений| ЕженедельникАПТЕКА. Available online: https://www.apteka.ua/article/487942 (accessed on 4 February 2020).

15. All pharmacy kiosks to close in Ukrainian cities - 20 July 2011. Available online: https://www.kyivpost. com/article/content/business/all-pharmacy-kiosks-to-close-in-ukrainian-cities-109016.html (accessed on 25 May 2019).

16. Pharmaceutical Market of Ukraine: Realities and Perspectives. Available online: https://daily.ua/en/ pharmaceutical-market-of-ukraine-realities-and-perspectives.html (accessed on 28 May 2019).

17. $40 \%$ of Ukrainian Pharmacy Market Accounted for by 20 Largest Pharmacy Chains -Pharma \& Healthcare Market in CEE \& CIS-PMR. Available online: http://ceepharma-sphinx.pmr-www.nazwa.pl/news/259822/ 40-of-ukrainian-pharmacy-market-accounted-for-by-20-largest-pharmacy-chains (accessed on 2 April 2019).

18. Rynek apteczny w Polsce. Available online: https://grantthornton.pl/wp-content/uploads/2019/02/Rynekapteczny-w-Polsce-RAPORT-Grant-Thornon-13-02-2019.pdf (accessed on 3 February 2020).

19. Zaprutko, T.; Kopciuch, D.; Paczkowska, A.; Sawicka, D.; Stachowiak, Z.; Bogdaniec, P.; Kus, K.; Nowakowska, E. Access to vaccination in the Greater Poland (Poland). Acta Poloniae Pharm. Drug. Res. 2019, 76, 195-201. [CrossRef]

20. Die Apotheken. Zahlen, Daten, Fakten. Available online: https://www.abda.de/fileadmin/user_upload/ assets/ZDF/ZDF_2018/ABDA_ZDF_2018_Brosch.pdf (accessed on 3 February 2020).

21. Gellad, W.F.; Choudhry, N.K.; Friedberg, M.W.; Brookhart, M.A.; Haas, J.S.; Shrank, W.H. Variation in Drug Prices at Pharmacies: Are Prices Higher in Poorer Areas? Health Serv. Res. 2009, 44, 606-617. [CrossRef] [PubMed]

22. Zaprutko, T.; Koligat, D.; Michalak, M.; Wieczorek, M.; Józiak, M.; Ratajczak, M.; Szydłowska, K.; Miazek, J.; Kus, K.; Nowakowska, E. Misuse of OTC drugs in Poland. Health Policy 2016, 120, 875-881. [CrossRef] [PubMed]

23. Lakić, D.; Stević, I.; Odalović, M.; Vezmar-Kovačević, S.; Tadić, I. Patients' willingness to pay for cognitive pharmacist services in community pharmacies. Croat. Med. J. 2017, 58, 364-371. [CrossRef] [PubMed]

24. Jaber, D.; Aburuz, S.; Hammad, E.A.; El-Refae, H.; Basheti, I.A. Patients' attitude and willingness to pay for pharmaceutical care: An international message from a developing country. Res. Social. Adm. Pharm. 2018, 15, 1177-1182. [CrossRef] [PubMed]

25. De Souza Cazarim, M.; Pereira, L.R.L. Cost-effectiveness analysis of pharmaceutical care for hypertensive patients from the perspective of the public health system in Brazil. PLOS ONE 2018, 13, e0193567. 
26. Bojke, C.; Philips, Z.; Sculpher, M.; Campion, P.; Chrystyn, H.; Coulton, S.; Cross, B.; Morton, V.; Richmond, S.; Farrin, A.; et al. Cost-effectiveness of shared pharmaceutical care for older patients: RESPECT trial findings. Br. J. Gen. Pract. 2010, 60, e20-e27.

27. Zaprutko, T.; Göder, R.; Kus, K.; Rakhman, L.; Bilobryvka, R.; Nowakowska, E. The Cost of Inpatient Care of Schizophrenia and Treatment Schedules Used in German Academic Center: Kiel. Psychiatr. Q. 2016, 87, 595-603. [CrossRef] [PubMed]

C 2020 by the authors. Licensee MDPI, Basel, Switzerland. This article is an open access article distributed under the terms and conditions of the Creative Commons Attribution (CC BY) license (http://creativecommons.org/licenses/by/4.0/). 